Published with Open Access at Journal BiNET

Vol. 04, Issue 01: 192-197

International

\title{
Entrepreneurial thinking and competitiveness in bakery industry in Delta State of Nigeria
}

\section{Helen Ngozi Nwewi ${ }^{1}$, Ebele Mary Onwuka ${ }^{1}$ and Ebide Ogbotubo ${ }^{2}$}

${ }^{1}$ Dept. of Business Administration, Faculty of Management Sciences, NnamdiAzikiwe University, Awka, Nigeria

${ }^{2}$ Dept. of Vocational Education, Faculty of Education, NnamdiAzikiwe University, Awka, Nigeria

\section{$\triangle$ For any information: ask.author@journalbinet.com}

Received: 13 May 2017; Revised: 27 July 2017 and Published online: 14 August 2017.

\begin{abstract}
The study investigated entrepreneurial thinking and competitiveness in bakery industry in Delta State, Nigeria. The research adopted 20 top leading entrepreneurs at their individual location in the state.One research question guided the study and one null hypothesis was tested at 0.05 level of significance. The design of the study was descriptive survey. There was no sample because of the size of the population. A 21 item questionnaire on a 5-point response options constituted the instrument used for data collection; which was validated by experts in entrepreneurial studies, measurement and evaluation. The internal consistency of the instrument found to be 0.82. The authors personally administered a total of 20 copies of the questionnaire to 20 entrepreneurs who constituted the population for the study.The entire copies were collected and analyzed using mean, standard deviation and t-test. While mean values were used to provide answer to the research questions, $t$-test was used to test the hypothesis. Standard deviation provided clue on respondents' nearness in their expressed opinions.Based on the results of the analysis of data collected, it was found that innovation is an element of entrepreneurial thinking that helps entrepreneurs in bakery industry in Delta State to gain competitive edge over others. They identified the use of modern bakery equipment, ability to offer product differentiation, ability to maintain value creation, flexible to effect changes as innovative ways that promote competitive advantage. It was recommended that entrepreneurs leading in bakery industry should continue to maintain their innovative ways and if possible improve on them, as well as good customers' relationship as their central target.
\end{abstract}

Key Words: Entrepreneur, Entrepreneurial thinking, Competitive advantage and Bakery industry

Cite Article: Nwewi, H. N., Onwuka, E. M. and Ogbotubo, E. (2017). Entrepreneurial thinking and competitiveness in bakery industry in Delta State of Nigeria. International Journal of Business, Management and Social Research, 04(01), 192-197.

Crossref: https://doi.org/10.18801/ijbmsr.040117.22

Article distributed under terms of a Creative Common Attribution 4.0 International License. 


\section{Introduction}

The environment of modern business is challenging and highly competitive as there is a high level of struggle among entrepreneurs particularly who is to gain larger percent of the market and industry, where its products and services are widely accepted. The high state of competitiveness in the business environment makes it more dynamic and complex. Rukevwe (2015) maintained that the movement in organization's business are becoming more complex rather than simple, dynamic than steady and aggressive in nature than tame. Every entrepreneur wants to take over the control of the setting and remain at the top forever. It takes entrepreneurs the application of entrepreneurial related thinking to triumph in the scene. Nnabuife (2009) indicated competition as one continuous presenting itself in different forms and shapes. Globally and locally, only organizations are able to change in response to the prevailing environment and growth that can succeed. The environment is so competitive to the extent that those at the bottom are devising to take over those entrepreneurs at the top, while those at the top are devising means to maintain their positions at the top. Robbins (2008) maintained that established organizationshave had to define themselves against both traditional competitors who developed new products and services and small entrepreneurial firms with innovative offerings. The crux of the whole sense is that every firm aspires to have a competitive advantage and edge over others. Thus, competitive advantage has been defined as superior value creation with the firm's ability to sustain competitive advantage equivalent to its ability to sustain added value. Barney (1991) stated that a firm has a competitive edge when it is implementing a value creating strategy not simultaneously being implemented by any current or potential competitor. Barney (1991) further said that for firm to have competitive advantage;

$>$ It must be valuable, in the sense that it exploits opportunities and or neutralize threat in a firm's environment.

$>$ It must be rare among firm's current and potential competitors.

$>$ There cannot be strategically equivalent substitutes for their resources that are valuable but neither rare nor imperfectly imitable.

$>$ It must be imperfectly imitable.

One of the widely accepted food items in Nigeria, particularly in Delta State is bread. Almost every one eats bread in Delta State. Almost up to 75 percent of breakfast diets in every household in Nigeria contain bread. There is a high level of demand of this commodity in Delta State; just as petrol in the petroleum market in the country. Entrepreneurs had seen the lucrative nature of the industry. So, a lot of small and medium scale based businessmen are shipping into it and launching out different techniques, to take advantage of the industry at different location in the state. While new entrepreneurs are resuming to replacing the position of the existing ones, the existing ones are equally advancing strategies to remain and maintain their positions in the industry. There are some bakeries like Lucky bread, Ebegha bread, Emu bread, Onos bread, Fantazia bread, exotic bread, Agofure bread, Ayakeme bread which since they came into existence at their individual location remained at the top, and no other old and new competitors in the industry had have not been able to gain competitive edge over them. One could wonder to know why despites the presence of many old and new entrepreneurs in the industry with their techniques and ideas, yet the competitive strength of the aforementioned still continued unabated, hence this study.

Entrepreneurial thinking as a new idea that deals with the capacity of an entrepreneur to do something in a new way that nobody has thought of. Entrepreneurial thinking is the ability that differentiates present and potential entrepreneur from direct or indirect competitor in any industry. Basic elements of entrepreneurial thinking include creativity, innovation, leadership, customer value learning, discounting good customer relationship, uniqueness, training and research, planning (Robert, 1997; Day, 1994; Barney, 1991). Steve and Mike (2000) maintained that entrepreneurs' ability to hire very bright and organized people freed him from the day-to-day, pressures of running the business so he could focus on finding new target and thinking up new ideas. Companies not only compete for customers, they also compete for employees. Thus, the competitive environment is such that compensate and benefit packages are being given special attention. Innovation as one of the elements of entrepreneurial thinking that deals with implementation of new and approved knowledge, ideas, and methods, processes, tools, equipment which lead to new and better products and services. 
Benson (2006) maintained innovation as an element of entrepreneurial thinking which every great and seasonal entrepreneur has to show in his business activities. Oladapo et al. (2004) maintained that the higher the significance of innovation introduced by the entrepreneur, the more difficult it is for competitor to copy it. Mc Adam and Keogh (2004) stated that the outlook of firm towards innovation has high score in the competitive environment so as to gain higher competitive lead. Innovation thus seen as one of the abilities of entrepreneurial mind that energizes the entrepreneur to foresee new products or service based ideas and new methods to materialize them or rebrand old products and/or service by introducing novel methods into it. Sam (1993) maintained power of deep discounting as an element of entrepreneurial mind that helps entrepreneur to gain a better stand stiff competition. Driven by more demanding customers, global competition, and slow-growth economies and industries, many organizations search for new ways to achieve and retain competitive advantage. Firms thus devise means for thinking about customer's value, customer value learning, and the related skills that managers will need to create and implement superior customer value strategies (Robert, 1997; Day, 1994).

Bakery industry is considered to be one of the lucrative enterprises in Nigeria, particularly Delta State. This is because bread is the most commonly patronized product in the state. As a result, the industry witnesses hundreds of its producers at different locations in the state. Out of the hundreds of its producers, the products of Lucky bread, Ebegha bread, Osogbo bread, Emu bread, Onos bread, Agofure bread, Fantazia bread, Exotic bread and Ayakome bread appear to have been taken the lead at their individual locations in the state, despite the presence of hundreds of old and new entrepreneurs. Barney (1991) maintained that a firm has competitive edge when it is implementing a value creating strategy not simultaneously being implemented by any current or potential competitor. However, despite the increase of old and new entrepreneurs in the bakery industry in Delta State, yet the products of Lucky bakery, Ebegha bakery, Osogbo, Ayakome, Agofure, Fantazia, Emu, Exotic bakeries seen to gain the control and competitive advantage over others in their individual location in the bakery industry.

The main objective of this study was to determine the extent of relationship between entrepreneurial thinking and competitiveness in Bakery Industry in Delta State of Nigeria. Specifically, the study examined the extent of relationship between innovation and competitive edgeof rural and urban entrepreneurs of bakery industry in Delta State of Nigeria.The following research question guided the study:

What is the extent of relationship between innovation and competitive edge of rural and urban entrepreneurs of bakery industry in Delta State of Nigeria? The following null hypothesis was tested at 0.05 alpha level of significance. There is no significant difference in the extent of relationship between innovation and competitive edge of entrepreneurs of bakery industry in their respective location in Delta State of Nigeria.

\section{Theoretical Framework}

The resent study made use of DavidMcClland's need for achievement theory.According to Chiekezie (2008), David McClland theory for need achievement maintained that people with high need for achievement have an intense desire for success and an equally intense fear for future. People with high need for achievement are motivated by challenging and competitive work situations. The application of the theory to the present study is that entrepreneurs are achievement oriented people. They have sense of initiative and are goal oriented. This drives towards achievement of the basis of activity for most entrepreneurs, which enable them operate and always on tops and strive for excellence anywhere they hire.

\section{Materials and Methods}

The study adopted a descriptive survey design. The population for this study comprised 20 leading entrepreneurs in bakery industry at their individual location in Delta State of Nigeria. Due to the fact that the population size was small and controllable, no sampling was conducted. Therefore the entire population was used for the study. A 21 item structured questionnaire was used to collect data from the respondents on the extent of relationship between innovative thinking and competitive advantage 
of entrepreneurs of Bakery Industry over competitors in their respective location in Delta State of Nigeria. The researcher used a five-point Likert scale questionnaire of strongly agreed, agreed, disagreed, strongly disagreed and undecided to answer the research questions. The instrument was validated by expert in entrepreneurial studies, measurement and evaluation; and the reliability was carried out using KunderRicardson 21 (KR-21) formula which yielded 0.57, (see Appendix A). 20Copies of the instrument were administered on the respondents and all were returned. Mean (x) and standard deviation (SD) statistical tools were used in data analysis. T-test was used to test the hypothesis. Item that has above 2.50 mean level is considered high extent and those that below 2.50 mean level is considered low extent.

\section{Results}

Table 01. Ways innovation relates withcompetitive advantage of entrepreneurs in bakery industry, Nigeria

\begin{tabular}{|c|c|c|c|c|}
\hline $\mathrm{S} / \mathrm{N}$ & Innovative ways and completive edge & $\mathrm{X}$ & SD & Decision \\
\hline 1 & Use of modern baking oven & 3.20 & 0.47 & High Extent \\
\hline 2 & Use of supper bread wrapper & 3.28 & 0.44 & High Extent \\
\hline 3 & Ability to offer product differentiation & 3.28 & 0.44 & High Extent \\
\hline 4 & Utilization of new production methods & 3.33 & 0.45 & High Extent \\
\hline 5 & $\begin{array}{l}\text { Provision of training and development for staff on the } \\
\text { use of modern bakery equipment }\end{array}$ & 3.00 & 0.39 & High Extent \\
\hline 6 & Availability of modern bakery equipment & 3.58 & 0.50 & High Extent \\
\hline 7 & Acquisition of NAFDAC approval & 3.58 & 0.50 & High Extent \\
\hline 8 & $\begin{array}{l}\text { Understanding the strength and weakness competing } \\
\text { firms }\end{array}$ & 3.15 & 0.41 & High Extent \\
\hline 9 & Awarding prize to hardworking staff & 2.93 & 0.38 & High Extent \\
\hline 10 & Use of slicing machine & 3.40 & 0.40 & High Extent \\
\hline 11 & Constant supply of KVA generator & 3.58 & 0.50 & High Extent \\
\hline 12 & Provision of strong supervisory team & 3.28 & 0.44 & High Extent \\
\hline 13 & Use of fairly and attractive pay package for workers & 3.58 & 0.50 & High Extent \\
\hline 14 & Creating sound accounting and record system & 3.55 & 0.49 & High Extent \\
\hline 15 & Use of standard electronic mixer & 3.38 & 0.50 & High Extent \\
\hline 16 & $\begin{array}{l}\text { Maintaining value creation and power of deep } \\
\text { discounting }\end{array}$ & 3.58 & 0.50 & High Extent \\
\hline 17 & $\begin{array}{l}\text { Ability to evaluate the benefits of using new baking } \\
\text { tools and application processes }\end{array}$ & 3.40 & 0.46 & High Extent \\
\hline 18 & Flexible to effect changes & 3.50 & 0.50 & High Extent \\
\hline 19 & Employment of labour intensive experts & 3.43 & 0.47 & High Extent \\
\hline 20 & Take your business to electronic media & 3.43 & 0.47 & High Extent \\
\hline 21 & $\begin{array}{l}\text { Provision of conducive working environment for } \\
\text { workers }\end{array}$ & 3.55 & 0.47 & High Extent \\
\hline
\end{tabular}

Table 01 shows that all the items were responded high extent by the respondents on the relationship of innovation and competitive advantage of rural and urban entrepreneurs of bakery industry in Delta State of Nigeria.

Table 02. T-test analysis of the means response of urban and ruralentrepreneurs on the relationship of innovation with competitive advantage of entrepreneurs of Bakery industry

\begin{tabular}{lllllll}
\hline Entrepreneurs & Mean & SD & N & t-cal & t-crit & Decision \\
\hline Urban & 20.25 & 7.09 & 12 & & & \\
\hline & & & & 0.780 & 1.960 & Accepted \\
\hline Rural & 16.02 & 3.40 & 8 & & & \\
\hline
\end{tabular}


Result obtained from the test of hypothesis 1 presented in Table 02 showed that the hypothesis was accepted at 0.05 level of significance. This result revealed that there was no significant difference between mean ratings of urban and rural entrepreneurs of bakery industry on the relationship of innovation with competitive advantage of entrepreneurs of bakery industry in their respective location in Delta State of Nigeria.

\section{Discussion}

The findings from table 01 on the research question one of this study have revealed that innovative ways on competitive edge in bakery industry as deployed by entrepreneurs at their individual locations in Delta State include the use of modern baking oven, ability to offer product differentiation, provision of training and development for staff, acquisition of NAFDAC approval, use of fairly and attractive pay package, employment of competent hands, use of standard electronic mixer, maintaining value creation, flexible to effect changes. Barney (1991) supported the findings that a firm has a competitive edge when it is implementing a value creating strategy not simultaneously being implemented by any current or potential competitor. Mc Adam and Keogh (2004) also agreed with the study that the outlook of firm towards innovation has high score in the competitive environment so as to gain higher competitive lead. Sam (1993) had similar findings with this study when he stated that power of deep discounting is an element of entrepreneurial thinking that helps entrepreneurs to gain a better stand in stiff competition. Robert (1997) and Day (1994) held that Firms thus devise means for thinking about customer's value, customer value learning, and the related skills that managers will need to create and implement superior customer value strategies.

\section{Conclusion and Recommendations}

Based on the findings of this study, it was concluded that innovative thinking encourages and promotes competitive edge of entrepreneurs of bakery industry in their respective location in Delta State and that Rural and urban entrepreneurs of bakery industry do not differ in the extent of relationship between innovation and competitive edge in Delta State of Nigeria.

Based on the findings of the study, the following recommendations were made:

$>$ Top leading entrepreneurs of bakery industry in Delta State should continue to maintain and improve on their innovative strength to enable them always remain at the top, and enjoy such advantage.

$>$ They should continue to treat customers as their centre target, and commit to themselves activities that guarantee customers trust on their products and effect changes from time to time to record customers' high patronage.

\section{References}

[1]. Barney, J. B. (1991). Firms resources and sustainable competitive advantage. Journal of Management, 17(1), 99-108. https://doi.org/10.1177/014920639101700108

[2]. Benson, 0. (2006). Small scale business and entrepreneurship. Maiduguri: Bless Abiona Printing Press.

[3]. Chiekezie, O. M. (2008). Administrative theory and practice. Awka: First Fountain Publishers (Nigeria).

[4]. Day, G. (1994). Capabilities of market-division organizations. Journal of Marketing, 58, 37-52. https://doi.org/10.2307/1251915

[5]. Mc Adam, R. and Keogh, K. (2004). Transitioning towards creativity and innovation management in SMEs. Creativity and Innovation. Management, 13(2), 14-126.

[6]. Nnabuife, E. (2009). Organizational behaviourand management theory. Nimo: rex Charles and Patrick limited.

[7]. Oladapo, P., Akpor, P., Ekatietie, E. S. and Omoyele, S. O. (2004). Introduction to business management. Lagos: More Ways Print Production. 
[8]. Robbins, S. P., Judge, T. A. and Sanghi, S. (2008). Organizational Behaviour (K.ed) New Delhi: Pearson prentice.

[9]. Robert, A. E. (2010). Entrepreneurship education top wealth creation and employments generation. Agbor: Krisbee Publication.

[10]. Robert, B. W. (1997). Customers value: the Next Source for Competitive advantage. Journal of the Academy of Marketing Science, 25(1), 3-9.

[11]. Rukevwe, J. O. (2015). Effect of Innovation on the Performance of Smes Organizations in Nigeria. Management, 5(3), 90-95.

[12]. Sam, W. (1993). Made in America: My story: Amenta Bantain Books.

[13]. Steve, M. and Mike, C. (2000). The very, very rich: profiles of phenomenal entrepreneurs. AbaOwerri: Overcomers Press. PMid:11079890 PMCid:PMC2243923 